\title{
EVALUASI Drung Related Problems (DRPs) ANTIBIOTIK PADA PASIEN PNEUMONIA RAWAT INAP ANAK RUMAH SAKIT UMUM DAERAH DELI SERDANG
}

\author{
CINDY MONICA ${ }^{1}$, AMINAH. $\mathbf{S}^{2}$, dan SITI DALILLA ${ }^{3}$ \\ INSTITUSI KESEHATAN MEDISTRA LUBUK PAKAM. \\ e-mail : cindymonica1990cm@gmail.com \\ DOI $10.35451 /$ jfm.v3i2.574
}

\begin{abstract}
Background: Infection is the top ten diseases in Indonesia, so that antibiotic therapy is quite high. The increasing use of antibiotics may lead to an increase in the use of irrational antibiotics. They are events that are not expected from the patient's experience or are suspected to be due to drug therapy so that they have the potential to interfere with the desired healing success.

Objective: This study aims to determine the number of occurrences of DRPs which include dosage inaccuracy, namely under and over dose, indication without drug, drug without indication, potential interactions and inaccuracy of drug selection in inpatient pneumonia treatment for children at the Deli Serdang Regional public hospital.

Method: This study is retrospective in which data is obtained through secondary data of patient medical records for the period January-December 2019 with a cross-sectional study design. The data collection technique was form of total sampling, obtained 50 samples that fit the inclusion criteria.

Results: Drung Related Problems (DRPs) research that occurred in the underdose category of drugs (4.0\%), and excessive drug doses (2.0\%) and no DRPs (94.0\%). This shows that the role of pharmacists is important in monitoring patient drug therapy to minimize the occurrence of DRPS
\end{abstract}

Keywords: Drung Related Problems (DRPs), Antibiotics, Pneumonia

\section{Pendahuluan}

Infeksi merupakan penyakit terbanyak di indonesia, sehingga terapi antibiotik cukup tinggi. Semakin banyaknya penggunaan antibiotik dapat bersifat irrasional. Salah satunya yaitu pemakaian tanpa resep. Data yang di peroleh WHO menunjukan bahwa $64 \%$ negara di asia tenggara memberikan antibiotik tanpa resep.

Penelitian tim AMRIN di dua rumah sakit pendidikan di Indonesia mendapatkan hanya $21 \%$ peresepan antibiotik yang tergolong rasional, penggunaan irrasional dapat meningkatkan angka resistensi bakteri terhadap antibiotik. Hasil penelitian antimicrobial resistant Indonesia (AMRIN Study) tahun 2000-2005 pada 2494 individu di masyrakat, memperlihatkan bahwa 43\% Escherichia coli resisten terhadap berbagai jenis golongan antara lain ampicilin (34\%), kotrimoksazol (29\%) dan kloramfenikol (25\%), antibiotik dapat dibuat secara sistensis atau semi sistensi (Rahmawati D, 2019).

Peningkatan dan perbaikan upaya perkembangan dan peningkatan kualitas hidup anak merupakan upaya 
penting untuk masa depan indonesia yang lebih baik. Anak dapat diartikan bahwa anak tidak meninggal pada awal kehidupan, yaitu tidak sampai mencapai usia satu tahun atau usia di bawah lima tahun, kelangsungan hidup anak tunjukan dengan angka kematian bayi (AKB) dan angka kematian balita (AKABA/AKBAL). Angka kematian bayi dan balita di Indonesia adalah tertinggi di negara ASEAN lainnya (Mayunani, 2018).

Virus tidak hanya merusak sel epitel bersilia tetapi juga goblet dan kelenjar musuk pada bronkus sehingga merusak clearance mukosilia. Apabila kuman patogen mencapai bronkoli terminalis, cairan edema masuk ke dalam alveoli, diikuti oleh leukosit dalam jumlah banyak, kemudian makrofog akan memberhasilkan debris sel dan bakteri (Nursalam, 2018).

Proses ini bisa meluas lebih jauh lagi ke segala atau lobus yang sama, atau mungkin ke bagian lain dari paruparu melalui cairan bronkial yang terinfeksi. Jaringan paru mengalami konsolidasi, maka kapasitas vital dan comlience paru menurun, serta aliran darah yang mengalami konsolidasi menimbulkan pirau/ shunt ke kiri dengan ventilasi perfusi yang mismatch, sehinga berakibat pada hipoksia (Nursalam, 2018).

Pneumonia merupakan salah satu penyebab dari 4 juta kematian pada balita di negara berkembang, khususnya pada anak. Kejadian pneumonia pada bayi dan balita di Indonesia di perkirakan antara $10 \%$ $20 \%$ per tahun. Program pemberantasan penyakit ISPA yang telah di laksanakan beberapa waktu lalu menetapkan angka $10 \%$ balita sebagai target penemuan penderita pneumonia bahwa $10 \%$ dari pneumonia akan meninggal bila tidak diberi pengobatan.
Perkiraan angka kematian pneumonia secara nasional adalah 6/1000 balita atau 150.000 balita per tahun. Menurut WHO, kriteria untuk menentukan bahwa kematian pneumonia pada balita masih merupakan masalah di suatu wilayah/negara, adalah apabila angka kematian akibat pneumonia pada balita di atas $20 \%$. Pneumonia masih menjadi masalah di Indonesia, karena angka kematian balita adalah 46/1000 kelahiran hidup dan angka kematian pneumonia balita diperkirakan sekitar 6/1000 balita (Maryunani, 2018).

Berdasarkan survey pendahuluan yang peneliti lakukan di RSUD Deli Serdang kususnya di ruangan rawat inap anak pada bulan Januari-Desember 2019 peneliti menemukan bahwa $80 \%$ penyakit pneumonia banyak terdapat pada anak dan pasien anak mendapatkan obat antibiotik untuk penyembuhan penyakit pneumonia.

Berdasarkan uraian diatas, maka peneliti tertarik untuk melakukan penelitian tentang Evaluasi drug relate problems (DPRs) antibiotik pada pasien pneumonia di ruang rawar inap anak di Rumah Sakit Umum Daerah Deli Serdang tahun 2020.

\section{METODOLOGI PENELITIAN}

Metode penelitian yang digunakan dalampenelitian ini adalah rancangan penelitiaan deskriptif bertujuan untuk menerangkan ataumengambarkan penelitian yang terjadi berdasarkan karakteristik. Data variabel yang dikumpulkan dalam penelitian ini dilakukan secara retropsektif dari data rekam medis pasien, pengambilan data di ambil dari data rekam medis di RSUD Deli Serdang. 


\section{Waktu}

Evaluasi data dilakukan selama maret-mei pada tahun 2020

\section{Lokasi Penelitian}

Penelitian ini dilakukan di RSUD Deli Serdang yang beralamat di Jl. Mh. Thamrin No. 126, Lubuk Pakam, Kec. Lubuk Pakam, Kabupaten Deli Serdang, Sumatra utara.

\section{Populasi dan sampel}

Populasi penelitian ini menujukan Evaluasi drug relate problems (DRPs) antibiotik pada pasien pneumonia di ruang rawar inap anak di Rumah Sakit Umum Daerah Deli Serdang dengan populasi penelitian adalah semua pasien pneumonia pada priode JanuariDesember 2019 yang diambil data pasien dari rekam medik sebanyak populasi 100 pasien pneumonia.

\section{Sampel}

Sampel adalah Evaluasi drug relate problems (DRPs) antibiotik pada pasien pneumonia di ruang rawar inap anak di Rumah Sakit Umum Daerah Deli serdang, sampel dalam penelitian ini menggunakan metode Rendom Sampling yaitu pengambilan secara acak dan mencampuran subjek-subjek di dalam populasi sehingga semua subjek diangap sama (arikunto, 2010). Besar sampel pada penelitian ini adalah 50 orang di peroleh dengan Rumus Minimal Slovin:

$$
\begin{gathered}
n=\frac{\mathrm{N}}{1+\mathrm{N}(\mathrm{d})^{2}} \\
n=\frac{100}{1+100(0,1)^{2}} \\
n=\frac{100}{1+100(0,01)} \\
n=\frac{100}{2} \\
n=50
\end{gathered}
$$

Keterangan :

$\mathrm{n}$ : jumlah sampel

$\mathrm{N}$ : jumlah populasi

d : tingkat kepercayaan/ ketepatan yang diinginkan (tingkat kepercayaan $90 \%$ )

\section{Kriteria Inklusi dan Ekslusi}

1. Kriteria inklusi
a. Pasien rawat inap tahun 2019.
b. Pasien yang berdiagnosa pneumonia yang mendapatkan terapi antibiotik.
c. Pasien dengan penyakit penyerta
d. Pasien dengan data rekam medis yang lengkap.

2. Kriteria ekslusi
a. Pasien yang tidak diberi Antibiotik
b. Semua pasien yang exit (meninggal dunia)

\section{Peralatan Penelitian}

Peralatan penelitian yasng digunakan untuk Evaluasi drug relate problems (DRPs) antibiotik pada pasien pneumonia di ruang rawar inap anak di Rumah Sakit Umum Daerah Deli adalah:

a. Pembuatan dan penyerahan surat permohonan izin pelaksanaan penelitian dari Institut Kesehatan Medistra Lubuk Pakam kepada Rumah Sakit Umum Daerah Deli Serdang.

b. Penyerahan surat persetujuan penelitian dari Rumah Sakit Umum Daerah Deli Serdangke pada Institut Kesehatan Medistra Lubuk Pakam.

\section{Pengumpulan Data}

1. Penelusuran data pada pasien pneumonia di ruang rawar inap anak di Rumah Sakit Umum Daerah Deli Serdang pada priode Januari-Desember 2019, karakteristik responden dilihat 
dari umur, jenis kelamin, penyakit penyerta.

2. Pengambilan data dan pencatatan data hasil rekam medis di ruangrekam medis, yaitu:

- Usia pasien

- Jenis kelamin pasien

- Tanggal perawatan

- Penyakit penyerta

- Data penggunaan obat, yaitu:

- Nama obat antibiotik

- Lama pemakaian antibiotik

- Tepat obat, tepat dosis

\section{Pengolahan data}

a. Editing data adalah upaya untuk memeriksa kembali kebenaran data yang di peroleh atau dikumpulkan. Editing dapat dilakukan pada tahap pengumpulan data atau setelah data dikumpil.

b. Coding data merupakan kegiatan memberika kode numerik(angka) terhadap data yang terdiri atas beberapa katagori. Pemberian kode ini sangat penting bila pengolahan dan analisis data menggunakan komputer.

c. Data entri adalah kegiatan memasukan data yang telah dikumpulkan ke dalam master tabel atau data base komputer, kemudian membuat distribusi frekuensi sederhana atau bisa juga dengan membuat tabel kotigensi.

d. Melakukan teknik analisis

Dalam melakukan analisis, khusunya terdapat data penelitian akan menggunakan ilmu statistik terapan yang disesuaikan dengan tujuan yang hendak dianalisis (Hidayat, 2007).

\section{HASIL DAN PEMBAHASAN}

\section{Proses Penelitian}

Penelitian Evaluasi Drung Related Problems (DRPs) Antibiotik Pada pasien Pneumonia Rawat inap anak Rumah Sakit Umum Daerah Deli Serdang yang di resep oleh dokter pada tahun 2019.

\section{Karakteristik Pasien}

Karakteristik pasien pneumonia pada anak di rumah sakit umum daerah deli serdang tahun 2019 meliputi dari jenis kelamin, usia dan penyakit penyerta. Berdasarkan pengambilan data jumlah pasien anak yang didiagnosa dengan pneumonia adalah 100 paisen dan didapat 50 pasien yang memenuhi kriteria inklusi dan ekslusi dalam penelitian dapat dilihat pada tabel 1.1 dibawah ini.

Tabel 1.1 Kriteria Pasien Pneumonia Pada Anak di Rumah Sakit Umum Daerah Deli Serdang

\begin{tabular}{|c|c|c|c|}
\hline $\begin{array}{l}\mathbf{N} \\
\mathbf{0}\end{array}$ & $\begin{array}{l}\text { Kategori } \\
\text { DRPs }\end{array}$ & $\mathbf{N}$ & $\begin{array}{c}\text { Persentase } \\
\%\end{array}$ \\
\hline 1 & $\begin{array}{c}\text { Ketidak } \\
\text { tepatan } \\
\text { pemilihan } \\
\text { obat }\end{array}$ & 0 & 0 \\
\hline 2 & $\begin{array}{c}\text { Dosis obat } \\
\text { berlebih }\end{array}$ & 2 & 4,0 \\
\hline 3 & $\begin{array}{c}\text { Dosis obat } \\
\text { kurang }\end{array}$ & 1 & 2,0 \\
\hline 4 & $\begin{array}{c}\text { Indikasi } \\
\text { tanpa } \\
\text { obat }\end{array}$ & 0 & 0 \\
\hline 5 & $\begin{array}{c}\text { Obat } \\
\text { tanpa } \\
\text { indikasi }\end{array}$ & 0 & 0 \\
\hline 6 & $\begin{array}{c}\text { Interaksi } \\
\text { obat }\end{array}$ & 0 & 0 \\
\hline 7 & $\begin{array}{c}\text { Tidak } \\
\text { terjadi } \\
\text { DRPs }\end{array}$ & 47 & 94,0 \\
\hline & Total & 50 & 100 \\
\hline
\end{tabular}




\section{Profil Penggunaan Obat}

Penggunaan obat pada pasien pneumonia anak di rumah sakit umum daerah dali serdang berdasarkan antibiotik yang digunakan pada pasien pneumonia anak dapat dilihat pada table 1.2 dibawah ini.

Tabel 1.2 Penggunaan Antibiotik Dan Obat Penyerta Untuk Pengobatan Pasien Pneumonia Anak Di Rumah Sakit Umum Daerah

\begin{tabular}{c|c|c}
$\begin{array}{c}\text { Penggunaan } \\
\text { aontibiotik }\end{array}$ & $\mathbf{N}$ & $\begin{array}{c}\text { Persentase } \\
\mathbf{\%}\end{array}$ \\
\hline Ceftriaxone & 34 & 68,0 \\
\hline Cefotaxime & 13 & 20,0 \\
\hline Meropenem & 3 & 6,0 \\
\hline Total & 50 & 100 \\
\hline $\begin{array}{c}\text { Penggunaan } \\
\text { obat penyerta }\end{array}$ & $\mathbf{N}$ & $\begin{array}{c}\text { Persentase } \\
\%\end{array}$ \\
\hline Ambroxsol & 16 & 64,0 \\
\hline Paracetamol & 5 & 20,0 \\
\hline Lacto B & 4 & 16,0 \\
\hline $\begin{array}{c}\text { Total } \\
\text { Deli Serdang }\end{array}$ & 25 & 100
\end{tabular}

\section{Drung Related Problems (DRPs)}

Evaluasi Drung Related Problems (DRPs) pada pasien di gambarkan deskritif dalam bentu persentasi kejadien Drps pada pasien pneumonia anak di rumah sakit umum daerah deli serdang, tahun 2019 dilihat pada tabel 1.3 dibawah ini.
Tabel 1.3 Kejadian DRPs yang Terjadi pada Pengobatan Antibiotik Terhadap Pasien Pneumonia Anak di Rumah Sakit Umum Daerah Deli Serdang.

\begin{tabular}{|c|c|c|}
\hline $\begin{array}{l}\text { Penggunaan } \\
\text { Antibiotik } \\
\text { Berdasarkan } \\
\text { jenis kelamin }\end{array}$ & $\mathbf{N}$ & Persentase \% \\
\hline Laki-laki & 28 & 56,0 \\
\hline Perempuan & 22 & 44,0 \\
\hline Total & 50 & 100 \\
\hline \multicolumn{3}{|l|}{$\begin{array}{l}\text { Berdasarkan } \\
\text { usia pasien }\end{array}$} \\
\hline $\begin{array}{c}\text { 2bulan - } \\
\text { 5tahun }\end{array}$ & 40 & 80,0 \\
\hline 6 - 12tahun & 10 & 20,0 \\
\hline Total & 50 & 100 \\
\hline \multicolumn{3}{|l|}{$\begin{array}{c}\text { Berdasarkan } \\
\text { penyakit } \\
\text { penyerta }\end{array}$} \\
\hline $\begin{array}{c}\text { Tanpa } \\
\text { penyakit } \\
\text { penyerta }\end{array}$ & 25 & 50,0 \\
\hline $\begin{array}{l}\text { Dengan } \\
\text { penyakit } \\
\text { penyerta }\end{array}$ & 25 & 50,0 \\
\hline Total & 50 & 100 \\
\hline \multicolumn{3}{|l|}{$\begin{array}{l}\text { Jenis penyakit } \\
\text { penyerta }\end{array}$} \\
\hline Bronkitis & 16 & 64,0 \\
\hline Anemia & 5 & 20,0 \\
\hline Diare & 4 & 16,0 \\
\hline Total & 25 & 100 \\
\hline
\end{tabular}

\section{PEMBAHAASAN}

\section{Berdasarkan}

tabel

1.1 menunjukan bahwa pasein pneumonia pada anak dengan jenis kelamin laki-laki lebih dominansi $(56,0 \%)$, dengan usia yang paling dominan adalah 2 bulan -5 tahun $(80 \%)$, sedangkan besar pasien pneumonia anak mengalami penyakit penyerta $(52,0 \%)$, dan adapun penyakit penyerta paling banyak dialami oleh pasien pneumonia anak adalah Bronkitis $(62,0 \%)$, anemia $(23,0 \%)$ dan Diare $(15,0 \%)$. 
Berdasarkan tabel 1.2 menunjukan bahwa sebagian besar antibiotik yang digunakan dalam kasus pneumonia pada anak Ceftriaxone $(68,0 \%)$, Cefotaxime $(26,0 \%)$ dan Meropenem $(6,0 \%)$ dan berdasarkan pengobatan penyakit penyerta menggunakan Ambroxsol (64,0\%), Paracetamol $(20,0 \%)$, dan Lacto B $(16,0 \%)$.

\section{Berdasarkan tabel 1.3}

menunjukan bahwa kasus DRPs paling banyak terjadi pada kategori dosis obat kurang $(2,0 \%)$,dosis obat berlebih $(4,0 \%)$ dan tidak terjadi DRPs $(94,0 \%)$.

\section{KESIMPULAN}

1. Karakeritik penderita pneumonia pada anak berdasarkan usia, jenis kelamin, dan penyakit penyerta yang paling banyak dengan rentang usia 2 bulan - 5 tahun, jenis kelamin ratarata laki-laki, dan dengan penyakit penyerta 25 pasien.

2. Jenis Drug Related Problems (DRPs) yang terjadi pada pasien pneumonia rawat inap anak salah satu rumah sakit umum daerah deli serdang adalah kategori ketidak tepatan pemilihan obat, dosis obat berlebih, dosis obat kurang, indikasi tanpa obat, obat tanpa indikasi dan interaksi obat. Namun pada hasil penelitian tidak ditemukannya jenis Drug Related Problems (DRPs) kategori ketidak tepatan pemilihan obat, indikasi tanpa obat, obat tanpa indikasi, interaksi obat.

3. Jumlah dan persentase Drug Related Problems (DRPs) yang terjadi adalah DRPs kategori dosis obat kurang sebanyak $64,0 \%$, dosis obar rendah sebanyak $36,0 \%$.

\section{SARAN}

Perlu adanya penelitian lebih lanjut dengan menggunakan data prospektif sehingga dapat mengamati kondisi pasien secara langsung memperoleh data yang lebih lengkap, serta dapat mengkaji DRPs kategori kepatuhan pasien, dan terkait dalam hasil evaluasi pengobatan yang dialami pasien dapat langsung di rekomendasikan dan didiskusikan dengan tenaga medis untuk lebih tepat memberi dosis obat kepada pasien agar mendapatkan pengobatan yang efektif dan rasional.

\section{DAFTAR PUSTAKA}

Arikunto, Suharsimi. 2010. Prosedur Penelitian. Yogyakarta: Rineka Cipta.

Ashraf mozayani dan lionel p. Raymon., 2014. Buku interaksi obat peomanklinis dan forensik. Jakarta : EGC

Djuanda, A. Dermatosis eritroskuamosa dalam buku ilmu penyakit kulit dan kelamin. Edisi Ketiga. Jakarta; Fakultas Kedokteran Universitas Indonesia; 1999.

DR.Maksum Radji, M., 2013. Mikrobiologi Panduan Mahasiswa Farmasi dan Kedokteran. Jakarta: EGC.

DR. Indan Entjang. 2001. Mikrobiologi dan Parasitologi Untuk AkademiKeperawtan Dan sekolah tinggi Kesehatan yang sederajat. Bandung: PT. Citra aditya bakti

Kementerian Kesehatan Republik Indonesia., 2011. Pedoman Penggunaan Antibiotik. Jakarta: Kemenkes RI.

Maryunani, Anik., 2018. Ilmu Kesehatan Anak Dalam Kebidanan. Jakarta: TIM.

Nursalam, dkk., 2018. Asuhan Keperawatan Bayi dan Anak. Jakarta: Salemba Medika.

Strand, L.M., Helper, D.D., 1990. Opportunitie and Responsibilities in Strand, L.M., and American : Journal of Hospital Pharmacy.

Volk, W.A dan Wheeler, M.F., 1993. Mikrobiologi dasar. Jilid I. Alih Bahasa : Markam jakarta : Erlangga. 